\title{
Pathways fostering Mobility to Higher Education for Vulnerable Immigrants in France, Switzerland and Canada
}

\author{
Jake Murdoch (Corresponding author) \\ IREDU, University of Burgundy Franche Comté \\ Pôle AAFE, 21065 Dijon, France \\ Tel: +33 380395452 \\ jake.murdoch@u-bourgogne.fr \\ ORCID iD: 0000-0002-1596-9207 \\ Christine Guégnard \\ IREDU/Céreq, University of Burgundy Franche Comté \\ Pôle AAFE, 21065 Dijon, France \\ Tel: +33 380395460 \\ christine.guegnard@u-bourgogne.fr \\ ORCID iD: 0000-0001-7220-2478 \\ Maarten Koomen \\ Institute of Sociology / TREE University of Berne \\ Fabrikstr. 8, 3012 Bern, Switzerland \\ Tel: +41316313045 \\ maarten.koomen@soz.unibe.ch \\ ORCID iD: 0000-0002-0375-5607 \\ Imdorf Christian \\ Institute of Sociology / TREE University of Berne \\ Fabrikstr. 8, 3012 Bern, Switzerland \\ Tel: +41316314840 \\ christian.imdorf@unibas.ch \\ ORCID iD: 0000-0002-8015-977X \\ Kamanzi Canisius \\ Department of administration and educational foundations, \\ Faculty of education, University of Montréal \\ Pavillon Marie-Victorin, H2V 2S9 Montréal, Canada \\ Tel: +1 5143435670 \\ pierre.canisius.kamanzi@umontreal.ca \\ ORCID iD: 0000-0002-2068-9488 \\ Meyer Thomas \\ Institute of Sociology / TREE University of Berne \\ Fabrikstr. 8, 3012Bern, Switzerland, Tel: +41316313823 \\ thomas.meyer@soz.unibe.ch
}

\section{Published as:}

Jake Murdoch, Christine Guégnard, Maarten Koomen, Christian Imdorf, Canisius Kamanzi \& Thomas Meyer (2017) Pathways fostering mobility to higher education for vulnerable immigrants in France, Switzerland and Canada. European Journal of Higher Education 7(1), 29-42.

DOI: $10.1080 / 21568235.2017 .1254918$

To link to this article: http://dx.doi.Org/10.1080/21568235.2017.1254918 


\begin{abstract}
In this article we wish to clarify not only if, but also how - through which institutional settings - higher education is accessed by students from vulnerable immigrant groups in France, Switzerland and Canada. We are interested in the possible educational mobility that immigrant youths can experience arising from country-specific educational policies designed to increase the enrolment in higher education, particularly the flow from upper-secondary vocational educational tracks to higher education ones. We analyse using panel data in each country the accessibility of different pathways to higher education while taking into account the characteristics of the students. In terms of educational mobility, in France the democratisation of educational system, including the development of the vocational baccalauréat, has enabled more youths of immigrant background to access higher education. In Switzerland and Canada there is more "cooling down" and down-streaming of their educational aspirations towards non higher education and more labour market oriented pathways.
\end{abstract}

\title{
Keywords
}

Access; educational mobility; pathways; vocational tracks; international comparison 


\section{Introduction}

In the last decades, educational policy measures have introduced vocationally orientated programmes at upper secondary level in several European countries enabling access to higher education. These measures aim to increase educational mobility of disadvantaged groups such as students with an immigrant background and those from low socio-economic households.

In this article we examine how educational institutions shape educational pathways from secondary to higher education for male and female students of immigrant origin and if immigrant students use the same pathways to higher education as students without an immigrant background. We compare France, Switzerland and Canada because these three countries have substantially different educational systems and implementations of 'vocationalised' pathways to higher education. Following the proposition of both Crul et al. (2012) and Griga and Hadjar (2014) to consider alternative routes to higher education when analysing the chances of immigrant students of becoming higher education students, we are primarily interested in how policies designed to increase enrolment in higher education - particularly programmes aiming at fostering transition from upper-secondary VET tracks to higher education - may affect educational mobility towards higher education. Whereas France has witnessed a vocationalisation of the route to higher education through the implementation of the specifically vocationally orientated track (baccalauréat professionnel), the new route to higher education in Switzerland has been created through the academisation of VET with the setting up of the Federal Vocational Baccalaureate (Murdoch et al. 2014). In contrast to France and Switzerland, the educational pathways are more flexible and permeable and the enrolment rates in higher education are higher in Canada. In the Canadian context, college and work preparatory courses (in contrast to university preparatory courses) on the post-secondary level can be considered an alternative pathway to higher education. Understanding the access to those different new vocational tracks to higher education for immigrant students is crucial to understand their access to higher education.

While France, Switzerland and Canada vary greatly in terms of their educational policy, they all have a sizeable immigrant population, who, in part, do experience obstacles in their educational and professional careers (see Brinbaum and Guégnard 2013 for France; Hupka and Stalder 2011 for Switzerland; Thiessen 2009 for Canada).

In France, the second-generation is large in comparison to other European countries. Of residents with an immigrant background, over half belong to the second-generation. Moreover, this second-generation is relatively young. Around 19 percent are between 18 and 24 years old (Bouvier 2012). In addition, 90 percent of the immigrant population aged between 20 and 35 have received their entire education in France. Today, 58 percent of second generation youths and 69 percent of French natives obtain a baccalauréat (Brinbaum and Kieffer 2009). These disparities persist with regard to access to higher education, with entrance rates of around 40 percent for the second generation and over half French youths with no migration background (Murdoch and Guégnard 2014). North African youths (i.e. those whose parents originate from Algeria, Morocco or Tunisia) are a particular vulnerability immigrant group in France when it comes to successful educational careers (Vallet 1996).

In Switzerland, one-fifth of students in Swiss higher education institutions are foreign nationals, but only one out of four of them have been schooled in Switzerland (OFS 2005). Given that young people with an immigrant background represent almost a third (29\%) of the resident population aged between 15 and 24 (Fibbi, Lerch, and Wanner 2006), Swiss-educated immigrant students are considerably underrepresented in higher education. Picot (2012), for example, shows that 35 percent of youth with no immigrant background, 26 percent of the second-generation, and only 17 percent of the first generation enrol for tertiary A level education by the age of 23. In the Swiss case, immigrants from Turkey and former Yugoslavia 
are among the most vulnerable in terms of societal acceptance and socio-economic position (Hupka and Stalder 2011).

Of the resident population in Canada (aged 15 and over), 24 percent belong to the first generation immigrants and 16 percent belong to the second-generation (Statistics Canada 2008). Independent of their academic performance, the proportion of young immigrants who enrol in higher education is markedly higher than the enrolment rates for natives. According to Finnie and Mueller (2010), around 85 percent of first and second generation youths access higher education compared to around 70 percent of the native Canadians. Amongst groups of immigrant, there are marked disparities depending on the country of origin. As noted in other studies, youths from Latin American and Caribbean countries have a higher dropout rate and enrol less in higher education than other immigrant groups (Abada, Hou, and Ram 2009).

In comparison, the relatively high representation of immigrant students in Canadian higher education could also be a result of different immigration policies. Compared to French and Swiss policies, the Canadian immigration policy used to be more selective and as a result, most labour immigrants in Canada are highly educated and qualified. Notwithstanding such policies and population differences, the specific characteristics of the Canadian educational systems will also account for a higher representation of students with an immigrant background in higher education. France and Switzerland both have a system of early tracking, which can form an obstacle for those who are socially disadvantaged. The Canadian educational system does not have such early tracking. Canada has a comprehensive general secondary school system followed by lightly stratified postsecondary academic and vocational programmes. Overall, Canadian general and academic education is more prestigious than vocational education. Vocational programmes matter more in both France and Switzerland. However, France's educational system is still predominantly a school-based, general educational system. In France, the status and prestige of traditional vocational education and training (VET) is low and therefore fails to attract a large proportion of well-performing students. The situation in Switzerland is very different. Only a small proportion of Swiss students enrolled in academic education. Nearly two thirds of students pursue VET programmes at upper secondary level.

The remaining of our article is structured as follows: in section 2, we will discuss how education systems characteristics may influence access to higher education for students with an immigrant background. In section 3, we outline the educational systems in the three countries, with a particular focus on previous empirical findings regarding new pathways to higher education and their usage by students with an immigrant background. In section 4 , we introduce our data and strategy for analysis. In section 5, we will discuss the results of our analysis and compare the three countries' varying educational pathways that lead to higher education. We finally summarise our findings and conclude in section 6 .

\section{Education System Characteristics and HE Enrolment of Immigrant Students}

The variability of immigrant students' access to higher education in the three countries of comparison raises the question of how national institutional settings influence educational mobility of vulnerable groups. According to Heath and Brinbaum (2014), factors influencing the chances of immigrant and non-immigrant groups to access higher education such as language, social background, educational aspirations, legal status and gender may be associated with characteristics of the educational system.

Stratified school systems and where pupils are tracked into different types of secondary schools early in their educational careers may be a barrier for students with an immigrant background. In case that immigrant groups are from a socially unprivileged background, language skills are an important factor for school selection in stratified systems (Tucci et al. 2013). In contrast, in comprehensive school systems whether educational decision are taken at 
a later stage, students with an immigrant background have more possibility to overcome over time such difficulties such as language skills. Griga and Hadjar (2014) show that low-stratified secondary school systems increase the likelihood of students with an immigrant background and low social origin attaining a higher education degree, whereas a stratified secondary school systems reduces it.

Finally, the characteristics of the educational systems may also affect the impact of educational aspirations on educational success. Choice-driven educational systems which are a feature of comprehensive school systems will be advantageous to youths with an immigrant background in Canada because it enables them to put into effect their higher educational aspirations (Heath and Brinbaum 2014). Comparative research in Switzerland and France (Griga, Hadjar and Becker 2013) as well as in Germany and France (Tucci et al. 2013) show that once students obtain an upper secondary certificate making them eligible for access to higher education, the probability of enrolling in higher education can be even higher for students with immigrant background when social origin is controlled for.

In their research on educational mobility of Turkish students in 12 European countries Crul et al. (2012) identify additional mechanisms to understand how school systems foster or impede educational success. School systems may demand different levels of parental involvement. Whereas more egalitarian systems require the parents to intervene less, stratified systems demand higher degrees of involvement and system knowledge for parents to support their children's educational success. Furthermore, the organisation of educational transitions to higher education, especially the availability of an alternative route to higher education through the vocational sector, may matter for immigrant students. Crul et al. identify four types of school integration contexts and of mobility based on national and regional probabilities that Turkish students leave school early and enrol in higher education. Whereas in inclusive contexts parents low educational level are no hindrance for their children's educational success (fast upward mobility, only children's learning abilities matter), inclusive vocational school integration contexts enable smooth transition to apprenticeship, with the route to higher education still remaining hampered (slow mobility). In permeable integration school context, in contrast, there exist both opportunities to stream up and down (resulting in polarized mobility). Finally, in exclusionary context social background matters most and makes even transition to higher education problematic (low mobility).

Crul et al. (2012) report a relatively low proportion of second-generation Turkish students enrol in tertiary education in Switzerland (15\%) compared to France (on average well over 30\%). However, the dropout rates during secondary school of this immigrant group appears to be lower in Switzerland than in France (13\% compared to between 10 and 20\% in France).

In the following section, we present in more detail the new or alternative pathways to higher education in the three selected countries in order to assess their potential to facilitate access to higher education for vulnerable immigrant students.

\section{New Pathways to Higher Education in France, Switzerland and Canada}

In France, the first important decision stages in the secondary system occurs at the age of 15 at the end of lower secondary (college), The access to upper secondary education and the allocation in the various tracks (academic, technological and vocational) is based on school performance, family wishes and teacher recommendations. After three years of upper secondary education, students take the baccalauréat and only those who attain this diploma gain access to higher education. The creation of a vocational baccalaureate in 1985 has enabled youths to access higher education, particularly those of working-class or immigrant background. After 
the end of lower secondary school, youths can first complete a short two-year vocational course (CAP/BEP) and then follow baccalauréat professionnel for two years.

With regard to the different types of school integration contexts proposed by Crul et al. (2012) the access to the baccalauréat professionnel represents an inclusive vocational school integration context, where the lycée professionnel offers the main access to vocational education. Strong academic competition at lower secondary education prepares for the tracking of different baccalauréat programs and restricts free educational choice. The French system therefore represents a mix of an inclusive vocational school integration system on the one hand and which is on the other hand embedded in an exclusionary academic context where social background matters for the transition to different baccalauréat programmes.

In Switzerland, unlike in France, only $20 \%$ of students enroll general baccalaureate schools (called Gymnasium) to obtain an academic baccalaureate (Matura, maturité), enabling access to higher education (universities or after an additional year of work experience, university of applied science). The majority of students that finish compulsory education at age 15 enrol in some form of vocational training (VET) that typically last between three to four years. Most of these VET programmes are organised in a mode termed as 'dual', where apprentices divide their time between a vocational school and a training company.

The second type of access to higher education other than the Gymnasium is the Federal Vocational Baccalaureate (Berufsmaturität, maturité professionnelle). It was created in the mid-1990s to adjust the Swiss education system to the Bologna reform and to facilitate transition from upper secondary VET to higher education (Nikolai and Ebner 2012). The Federal Vocational Baccalaureate is obtained after following basic VET training at upper secondary level and enables access to the Universities of applied sciences.

Hence, with respect to the Crul et al. (2012) typology of school integration contexts, the Swiss transition system into VET shows multiple facets. Hence, the Swiss educational system represents a mix of an exclusive context with respect to its early school selection and tracking at lower secondary level (the educational tracks anticipate the transition into either the academic vs. the vocational track), an inclusive vocational school integration context which offers smooth transition to apprenticeship for majority students at upper secondary level.

In the case of Canada, the majority of students who finish compulsory secondary school at age 16 enrol in postsecondary education, and particularly the university sector. If there is no formal academic/vocational tracking secondary school in Canada, there are two types of preparatory courses in language, mathematics or sciences that students can take during secondary school: university preparatory courses and college/work preparatory courses. Most of students take university preparatory courses in language, mathematics or sciences in order to maximize their chance of being accepted in their desired program. These preparatory courses aim to increase the performance of students who aspire to higher education. They can therefore be considered as a functional equivalent of baccalaureate programmes in Switzerland and France. Even though Canada was not one of the countries covered by the study by Crul et al., it is possible to include the country in the upward mobility model within the typology described by the authors, due to absence of formal tacking within secondary education.

\section{Data and Methodology}

We use panel data from France (DEPP), Switzerland (TREE), and Canada (YITS) and analyse how students with and without an immigrant background access higher education. In our analysis, we consider both first and second-generation immigrants. However, because immigrant students in general are a highly diverse group, we focus on youth from particular vulnerable groups (irrespective of the generation status) to analyse equivalent groups between the three countries. 
For the French DEPP panel, the Ministry of Education followed a nationally representative sample of students (17,830 youths) who entered the first year of secondary school in 1995 for a period of ten years. The youths were surveyed from lower secondary (collège) to upper secondary (lycée), and higher education. We compare the educational pathways of first and second generation students from North African origin (890 individuals from Algeria, Morocco, and Tunisia) with the educational trajectories of French students with two native French parents $(13,806$ respondents).

The Swiss Transitions from Education to Employment (TREE) panel study is a PISA 2000 follow-up survey with a nationally representative sample of students leaving compulsory school after the $9^{\text {th }}$ grade. TREE has surveyed nine times from 2001 to 2014 . In Switzerland, we consider the educational pathways of first- and second-generation youths from Turkey and former Yugoslavia (328 respondents) and compare them with respondents that have at least two Swiss-born parents $(4,430){ }^{1}$

The Canadian Youth in Transition Survey (YITS) is a joint project of Statistics Canada and Human Resources and Skills Development Canada. Designed as a PISA 2000 follow-up, it is similar to the Swiss TREE. Launched in 2000, YITS spanned six cycles over eight years. The first cycle (2000) covers the PISA sample, with subsequent cycles (2 to 6) covering twoyear periods from 2000 to 2008. In Canada, we compare first and second generation Latino and Caribbean youths ( 737 respondents) with Canadian students without an immigrant background $(10,947)$.

Using multinomial logistic regression, we analyse how having an immigrant background increases the likelihood of following a particular educational pathways to higher education. In consecutive regression models, we control for previous individual school performance (e.g. grades, reading skills and competency test), social background, gender, and aspirations. To enhance the comparability of results between regression models and countries, we calculate and present the average marginal effects of having an immigrant background on the likelihood of being in a particular educational pathway. With this method, we limit potential biases in our estimates due to unobserved heterogeneity (Mood 2010).

Tables 1 to 3 shows descriptive information with regard to the most important social and school variables that we will include in our analysis. There are some clear differences between the countries. For those without an immigrant background, for example, 27 percent of the respondents in France have at least one parent that has attained a higher education diploma of some kind. In Switzerland this share is 38 percent (including university and higher professional diploma), and in Canada it is 65 percent (16\% university degrees and $49 \%$ nonuniversity postsecondary diploma). In spite of such cross-national variations, a comparison across groups does highlight a persistent social vulnerability of the chosen immigrant groups in each country when compared to students with two native parents. In all three countries, students with no immigrant background have higher educated parents, a more advantageous social background, and better academic achievements. In France and Switzerland, students with an immigrant background also have lower educational (France) and occupational (Switzerland) aspirations. In Canada, students with a Caribbean or Latin-American background actually have higher educational aspirations in comparison to the students with two native parents.

\section{[Table 1 near here] [Table 2 near here] [Table 3 near here]}

\footnotetext{
${ }^{1}$ These sample figures are un-weighted and refer to the start sample in 2001. In the 2010 sample, 3,309 respondents without an immigrant background, and 213 respondents with a Turkish or Ex-Yugoslav background remain.
} 
We use the concept of educational pathways to compare routes through secondary education and the accessing of higher education in France, Switzerland and Canada. We use a broad definition of higher education (HE) to include various educational programmes that correspond to level 5 according to UNESCO's International Standard Classification of Education. French HE includes universities, short vocational tertiary programmes (IUT/STS) as well as other types of HE programmes. ${ }^{2}$ Swiss HE includes universities and universities of applied science (excluding higher vocational education and training) and Canadian HE includes universities and colleges (Cégep in Quebec and community college in the rest of Canada). We do not distinguish the different higher education tracks in each country in an effort to keep our cross-national analysis relatively easy to interpret.

For our analysis, we make the distinction between four different pathways: (1) academic pathways to higher education; (2) vocational pathways to higher education; (3) non-tertiary pathways despite of available HE entry qualification, and; (4) pathway without any type of HE entry qualification. Table 4 gives an overview of the pathways by country and country specific type of upper-secondary qualifications.

\section{[Table 4 near here]}

Table 4 shows the un-weighted distributions of students with and without an immigrant background across our four defined educational pathways in France, Switzerland, and Canada. In our definition of educational pathways, we exclude young people that have no upper or postsecondary certificate, i.e. those that drop out of secondary education and those that enter the labour market directly after leaving compulsory education. The analysed pathways do therefore not account for students without any upper or postsecondary certificate. According to official education statistics, the ratio of young people without such certificates amounts to around 10 percent in both France and Switzerland. The analysed groups of students with an immigrant background may be considerably overrepresented among those without upper or postsecondary certificates in both countries. In Canada, there is not such a clear distinction between upper secondary and higher education. In our sample, only 2 percent of students without an immigrant background do not follow any university, college, or work preparatory courses, and all students that have a Caribbean or Latin-American background either enrol for university, college, or work preparatory courses. Note that in Canada there is no formal tracking before pursuing these courses.

With our data and definition of educational pathways, we can see if the integration context typology of Crul et al. (2012) (slow, low, polarized and upward mobility) fits. In France, the percentage of students with an immigrant background that access higher education via the vocational pathway is higher (31\%) than for students with no immigrant background $(22 \%)$. We can say that this illustrates the slow/upward mobility case for immigrants in France. In Switzerland, however, students with an immigrant background do not seem to use the vocational route to higher education in the same compensating way. Just 11 percent of students use this route, compared to 13 percent of students with two native parents. Here we have a case of low mobility (which slightly goes against our initial hypothesis). Finally, in Canada, both students with- and without an immigrant background access higher education via the academic pathway in high proportion (61\%). This is a good illustration of upward mobility for the immigrant group. However, over a third $(36 \%)$ of the immigrant group do not enter higher education even though they are eligible. This could be indicate that there is some downstreaming and polarized mobility in Canada.

\footnotetext{
${ }^{2}$ Preparatory schools for business and engineering, art, architecture, nursing, and social work.
} 


\section{Results}

In our analysis, to see if there remains an immigrant background effect, we control for gender, ability, parental cultural and economic capital, and future study and job aspirations. We run three consecutive multinomial logistic regression models to predict the likelihood of being in a particular educational pathway. In a first model, we have immigrant background (IB) as the only independent variable. In a second step, we introduce previous school performances, ability scores, and other school variables (SP). In the last model, we add gender, future aspirations, parental education and the socio-economic status of the student's parents (SB). Table 5 shows the average marginal effects of having an immigrant background on being in a respective educational pathway, presented separately for each pathway and regression model.

For the first pathway, French students with an immigrant background have an 18percentage point lower probability to access higher education through the traditional, academic route (model 1). This difference dissolves completely once lower secondary school performance and ability is accounted for (model 2). When we additionally control for gender, social background, and aspirations (model 3), students with an immigrant background have a higher probability of accessing higher education via the academic route (7-percentage points).

Switzerland shows a similar pattern, albeit somewhat less pronounced. In the first regression, students with an immigrant background have a 9-percentage point lower probability of accessing higher education via the academic pathway. In Switzerland, the previous school performance explain the low representation of students with an immigrant background in the academic route to higher education (this includes lower-secondary school track). With similar school performance and track-placing, Swiss students with an immigrant background have a higher probability of following the academic route to higher education (although the result is not statistically significant).

In Canada, these patterns look very different. While there are hardly any disparities between students with- and without an immigrant background in the first model, the disadvantage of students with an immigrant background increases once we control for school achievement (11-percentage point difference). This gap decreases to some degree when gender, family background and aspirations are controlled (4-percentage point difference).

To interpret this counter intuitive result, we refer to rational action theory for youths of low social background (Becker and Hecken 2008). According to this theory, the influence of school performances plays out differently according to social background. Contrary to youths with high school performance for whom higher education studies is almost self-evident choice, no matter the social background, the reasoning is different in the case of youths with low or average performance. With similar low or average grades, youths from low social backgrounds are more likely to forfeit higher education studies in favour of vocational training. The choice of higher education studies is considered, in certain cases, as a too ambitious, non-realist and sometimes risky adventure. The situation appears similar for youths in Canada of Latin American and Caribbean origin. Generally, they follow higher education studies if they feel their school performance is high enough for this type of study. If this is not the case, they prefer to choose vocational training or the labour market (Thiessen, 2009).

Across all three countries, the gaps between the groups of students who accesses tertiary education via vocational routes (pathway 2, model 1) hardly change once we control for school performance. In Canada, this gap also does not change much when we control for gender, socio-economic status, and aspirations. Students with an immigrant background have an 11percentage point lower probability of accessing higher education through a vocational programme. Here also we can explain this difference by the effect of higher self-selection on the part of immigrants: taking up higher education studies after college or work preparatory courses can appear too ambitious. 
Likewise, in Switzerland, students with an immigrant background have a lower probability of following the vocational pathway to higher education. In the third model, this gap amounts to a 7-percentage point lower probability for Swiss students with an immigrant background.

In France, this pattern looks different. French students with an immigrant background have a 9-percentage point higher probability of following the vocational route to higher education compared to students without an immigrant background. However, once we control for social background, gender and aspirations, this figure is reduce to a 3-percentage point higher probability for students with an immigrant background.

[Table 5 near here; page format horizontal] 
A comparison of students with higher education entry qualifications who do not enrol into any tertiary institution (pathway 3), shows a linked pattern with the fist pathway for France and Canada, but not Switzerland. Once we control for school performance, aspirations and other variables, French student with an immigrant background are less often in this third pathway. In Switzerland, there is no clear difference between the two groups of students in any of the consecutive regression models. In Canada, we find a surprising pattern. When we control for school performance and ability, students with an immigrant background appear to be considerably overrepresented in the third pathway (23-percentage point higher probability in model 2, and 19-percentage points in model 3). This category includes students who, even though they have followed university or college preparatory courses, have too weak results to be admitted to higher education studies or decide themselves to give up as they are uncertain to succeed.

Finally, the figures for all other upper-secondary diploma holders who are not eligible for higher education (pathway 4) confirm the decisive meaning of school career characteristics in understanding the representations in different educational pathways. In both France and Switzerland, students with an immigrant background reverse their over-representation (model 1) in the 'traditional' VET-pathway once we control for school performance and social background. Swiss and French students without an immigrant background with similar school performance and social background now have equal or even a higher probability of being in an educational pathway that does not grand them entry qualifications for higher education. In Canada, this educational pathway is practically non-existent and we therefore did not include it in our regression analysis.

\section{Conclusion}

The aim of this article was to examine how educational pathways foster educational mobility of vulnerable immigrants or contribute to maintain segregation in accessing higher education among vulnerable immigrants and non-immigrant majorities. Three countries were compared: France, Switzerland and Canada. In all three countries of comparison, the selected immigrant groups - which are known to be particularly vulnerable - are under-represented in higher education. This paper has attempted to determine how institutional settings such as the development of alternative pathways in the three countries influence access to higher education.

As far as VET pathways to higher education are concerned, vulnerable immigrant students do indeed seem to benefit from them to compensate for their underrepresentation in the academic tracks to higher education, especially in France (slow/upward mobility). In the Swiss case, our data does not corroborate the compensation function of VET-based access to higher education (we find mainly only slow mobility). This might be due to access barriers for the immigrant groups under study in the transition from lower secondary school to upper secondary VET tracks. Their frequent relegation to bridge-year courses, where students often accept to decrease ("cool down") their occupational aspirations to a level where a vocational baccalaureate is not anymore an option, may be provoked by employer discrimination (Imdorf 2010).

For Canada, students from Latino and Caribbean backgrounds have pronouncedly lower odds than natives to access higher education, mainly because they do not make use of college/work preparatory courses to access higher education. This is not due to social background and school performance variables. Our results corroborate prior research conclusions (Finnie and Mueller 2010; Thiessen 2009). Indeed, even if the majority of Latino and Caribbean youth access higher education (upward mobility), over a third of these youths appear to have their aspirations cooled down, as in Switzerland, towards the more labour market oriented pathways (polarized mobility). Moreover, the influence of university preparatory 
courses on the access to higher education studies plays out differently between immigrant and the native group depending on school performance. For the former this association is only positive when school performance is high.

Looking at access to higher education in France, our results are very similar to those in Switzerland: Once we control for lower secondary school and achievement variables as well as for social background and aspirations, it is the non-immigrant rather than the immigrant students from North Africa who run a considerably higher risk of not finding their way into higher education. The same holds true for Ex-Yugoslav and Turkish students in the Swiss case, once we control for the same variables. Our results confirm recent findings, according to which immigrant children in France are more likely to obtain the baccalauréat than the native French (Vanholffelen 2013) when controlling for educational characteristics. The higher probability of obtaining a baccalauréat for immigrant youths reflects a strong aspirations with regard to educational mobility (Brinbaum and Kieffer 2009; Griga, Hadjar, and Becker 2013). Picot (2012) concludes for Switzerland, that once academic achievement and tracks attended at lower secondary level are controlled for, the heightened risk of the immigrant groups under study to be barred from accessing higher education disappears. These findings confirm the fact that inequalities in higher education participation rates between non-immigrant and immigrant youth lie in the early disadvantages during primary and lower secondary schooling, particularly early tracking. They need to be tackled at this level, rather than at the crossroads at the end of upper secondary education. 


\section{Biographical notes on contributors}

Jake Murdoch, Associate professor at the University of Burgundy (France), Institute for Research in the Sociology and Economics of Education (IREDU). Research topics: Educational pathways, school-to-work transitions, comparative education.

Christine Guégnard, Senior researcher at the University of Burgundy (France), Institute for Research in the Sociology and Economics of Education (IREDU)/Centre for Research on Education, Training and Employment (CEREQ). Research topics: School-to-work transitions, gender inequalities, vocational training.

Maarten Koomen, Data manager for the Transition from Education to Employment (TREE) panel survey, University of Bern (Switzerland), Institute of Sociology. Research topics: Migration related topics, particularly the social and cultural integration of minorities.

Christian Imdorf, SNSF professorship at the University of Bern (Switzerland), Institute of Sociology. Research topics: Sociology of education and work, education-employment transitions, early job-insecurity and labour market exclusion, international comparison.

Canisius Kamanzi, Assistant professor at the University of Montreal (Canada), Faculty of Education. Research topics: Education policy analysis, educational trajectories and social inequalities.

Thomas Meyer, Co-head of the Transition from Education to Employment (TREE) panel survey, University of Bern (Switzerland), Institute of Sociology. Research topics: Sociology of education, school-to-work transitions, educational inequalities. 


\section{References}

Abada, T., F. Hou, and B. Ram. 2009. "Ethnic Differences in Educational Attainment among the Children of Canadian Immigrants." Canadian Journal of Sociology/Cahiers canadiens de sociologie 34 (1): 1-28.

Becker R., and A.E. Hecken. 2008. "Why are Working-class Children Diverted from Universities? An Empirical Assessment of the Diversion Thesis." European Sociological Review 25 (2): 233-250.

Bouvier, G. 2012. "Les descendants d'immigrés plus nombreux que les immigrés : une position française originale en Europe, Immigrés et descendants d'immigrés en France." Insee Références - Édition 2012: 11-26.

Boyd, M. 2002. "Educational offspring: success or segmented assimilation?" International Immigration Review, vol. 36 (4): 1036-1060.

Brinbaum, Y., and C. Guégnard. 2013. "Choices and Enrollments in French Secondary and Higher Education: Tensions and Repercussions for SecondGeneration Immigrants." Comparative Education Review 57 (3) Special Issue on Faire Access to Higher Education: 481-502.

Brinbaum, Y., and A. Kieffer. 2009. "Trajectories of Immigrants' Children in Secondary Education in France: Differentiation and Polarization." Population-E 64 (3): 507-554.

Crul, M.R.J., Ph. Schnell, B. Herzog-Punzenberger, R. Aparicio Gómez, M. Wilmes, and M. Slootman. 2012. "School careers of second generation youth in Europe: Which education systems provide the best chances for success?" In The European Second Generation Compared. Does the Integration Context Matter?, edited by Crul, M.R.J., J. Schneider, and F. Lelie, 101-165. Amsterdam: Amsterdam University Press.

Fibbi, R., M. Lerch, and P. Wanner. 2006. "Unemployment and Discrimination against Youth of Immigrant Origin in Switzerland: When the Name Makes the Difference." Journal of International Migration and Integration 7 (3): 351-366. doi: 10.1007/s12134-006-1017-x.

Finnie, R., and R. E. Mueller. 2010. "They came, they saw, they enrolled : access to postsecondary education by the children of Canadian immigrants.", In Pursuing Higher Education in Canada Economic, Social, and Policy Dimensions, edited by Finnie ,R., M. Frenette, R. E. Mueller, and A. Sweetman, 192-216. Kingston: Queen's University Press.

Griga, D., and A. Hadjar. 2014. "Migrant Background and Higher Education Participation in Europe: The Effect of the Educational Systems." European Sociological Review 30 (3): 275286. doi: 10.1093/esr/jct031.

Griga, D., A. Hadjar, and R. Becker. 2013. "Bildungsungleichheiten beim Hochschulzugang nach Geschlecht und Migrationshintergrund: Befunde aus der Schweiz und aus Frankreich." In Geschlecht, Migrationshintergrund und Bildungserfolg, edited by Hadjar, A., and S. Hupka-Brunner, 270-293. Weinheim: Beltz Juventa Verlag.

Heath, A. F., and Y. Brinbaum. 2014. Unequal Attainments. Ethnic Educational Inequalities in Ten Western Countries. Proceedings of the British Academy 196, Oxford: Oxford University Press.

Hupka, S., and B. Stalder. 2011. "Jeunes migrantes et migrants à la charnière du secondaire I et du secondaire II". In Transitionen im Jugendalter: Ergebnisse der Schweizer Längsschnittstudie TREE, edited by Bergman M., S. Hupka-Brunner, A. Keller, T. Meyer and B. Stalder, 183-200. Zürich: Seismo.

Imdorf, C. 2010. "Die Diskriminierung 'ausländischer' Jugendlicher bei der Lehrlingsauswahl." In Diskriminierung. Grundlagen und Forschungsergebnisse, edited by Hormel, U., and A. Scherr, 197-219. Wiesbaden: VS Verlag für Sozialwissenschaften.

Mood, C. 2010. "Logistic Regression: Why We Cannot Do What We Think We Can Do, and What We Can Do About It." European Sociological Review, 26 (1): 67-82. 
Murdoch J., Guégnard C. 2014. "Les jeunes d'origine maghrébine en France et l'enseignement postsecondaire", in Intégration des familles d'origine immigrante - Les enjeux sociosanitaires et scolaires edited by Kanouté F. et Lafortune G., 159-174. Montréal: Presses de l'Université de Montréal.

Murdoch, J., Guégnard, C., Koomen, M., Imdorf, C., and S. Hupka-Brunner. 2014. "Pathways to higher education in France and Switzerland. Do vocational tracks facilitate access to higher education for immigrant students?" In Higher Education in Societies - A Multi Scale Perspective, edited by Goastellec, G. and F. Picard, 149-169. Rotterdam: Sense publishers.

Nikolai, R., and C. Ebner. 2012. "The Link between Vocational Training and Higher Education in Switzerland, Austria, and Germany." In The Political Economy of Collective Skill Formation, edited by Busemeyer, M.R., and C. Trampusch, 234-258. Oxford: Oxford University Press.

OFS (Office fédéral de la statistique). 2005. Internationalität der Schweizer Hochschulen. Studierende und Personal: eine Bestandesaufnahme. Neuchâtel: OFS.

Picot, G. 2012. "Immigrant Status and Secondary School Performance as Determinants of PostSecondary Participation: A Comparison of Canada and Switzerland." OECD Education Working Papers 77. Paris: OECD Publishing.

SKBF, 2011. Swiss Education Report 2010. Aarau: Swiss Coordination Centre for Research in Education.

Schmid, E., and P. Gonon. 2011. "Übergang in eine Tertiärausbildung nach einer Berufsausbildung in der Schweiz."bwp@ Spezial 5: 1-17.

Statistics Canada, 2008, Ethnic diversity and immigration, Canada Year book 2008. Ottawa: Statistics Canada.

Thiessen, V. 2009. "The pursuit of postsecondary education: a comparison of First Nations, African, Asian, and European Canadian Youth." Canadian Review of Sociology 46 (1): 5-37. doi: 10.1111/j.1755-618X.2009.01201.x.

Tucci, I., Jossin, A., Keller, C., and Groh-Samberg, O. 2013. "L'entrée sur le marché du travail des descendants d'immigrés : une analyse comparée France-Allemagne." Revue française de sociologie 54: 567-596.

Vallet, L.A. 1996. "L'assimilation scolaire des enfants issus de l'immigration et son interprétation: un examen sur données françaises." Revue française de Pédagogie 117: 7-27. doi: 10.3406/rfp.1996.1182.

Vanholffelen, A. 2013. "Les bacheliers du panel 1995 : évolution et analyse des parcours.", Note d'information 10.13, Direction de l'évaluation et de la prospective, Ministère de l'Education nationale. 


\section{Tables}

Table 1. Social and schooling characteristics in secondary school of students for France

\begin{tabular}{lcc}
\hline Country of parental origin & North Africa & France \\
\hline Parents higher education diploma & $2 \%$ & $27 \%$ \\
High socio-economic status & $2 \%$ & $26 \%$ \\
Low socio-economic status & $90 \%$ & $50 \%$ \\
Belated entry in secondary school & $42 \%$ & $18 \%$ \\
Above average marks (language) & $27 \%$ & $59 \%$ \\
Above average marks (mathematics) & $23 \%$ & $58 \%$ \\
Aspirations to study in HE & $45 \%$ & $53 \%$ \\
$N$ & 890 & 13 ' 806 \\
\hline
\end{tabular}

Source: Students' panel of secondary school, survey 1995-1995-2011 (2006) [electronic file], DEPP | INSEE [producer], Centre Maurice Halbwachs [diffuser]. 
Table 2. Social and schooling characteristics in secondary school of students for Switzerland

\begin{tabular}{lcc}
\hline Country of parental origin & $\begin{array}{c}\text { Turkey/ Ex- } \\
\text { Yugosl. }\end{array}$ & Switzerland \\
\hline Parents higher education diploma & $20 \%$ & $38 \%$ \\
High socio-economic status & $10 \%$ & $37 \%$ \\
Low socio-economic status & $62 \%$ & $23 \%$ \\
Basic requirements lower secondary school track & $47 \%$ & $22 \%$ \\
Above the mark (languages) & $59 \%$ & $74 \%$ \\
Above the mark (mathematics) & $55 \%$ & $64 \%$ \\
PISA reading score (above OECD average) & $31 \%$ & $72 \%$ \\
High future job aspirations & $18 \%$ & $25 \%$ \\
$N$ & 328 & $4{ }^{\prime} 430$ \\
\hline
\end{tabular}

Source: TREE (Transition from Education to Employment) 2000-2010. 
Table 3. Social and schooling characteristics in secondary school of students for Canada

\begin{tabular}{lcc}
\hline Country of parental origin & $\begin{array}{c}\text { Caribbean, } \\
\text { Latin America }\end{array}$ & Canada \\
\hline Parents higher education diploma & $33 \%$ & $65 \%$ \\
High socio-economic status & $4 \%$ & $24 \%$ \\
Math grades average above $80 \%$ & $18 \%$ & $33 \%$ \\
Language grades average above 80\% & $9 \%$ & $35 \%$ \\
PISA reading score (above OECD average) & $24 \%$ & $73 \%$ \\
Student's aspirations to study in HE at 15 & $62 \%$ & $55 \%$ \\
Parental aspirations to study in HE & $63 \%$ & $58 \%$ \\
$N$ & 737 & 10 ' 947 \\
\hline
\end{tabular}

Source: YITS (Youth in Transition Survey) cycles 2 to 5. 
Table 4: Construction of educational pathways by country

Pathway 1:

Academic pathway to higher education (HE)

No immigrant Immigrant background background

FR HE access via academic baccalaureate

$38 \%$

$20 \%$

$\mathrm{CH} \mathrm{HE}$ access via academic baccalaureate

$37 \%$

$26 \%$

CA HE access via university preparatory courses (language \& math) $61 \%$

$61 \%$

\section{Pathway 2:}

Vocational pathway to higher education

No immigrant Immigrant background background

FR HE access via vocational baccalaureate

$22 \%$

$31 \%$

$\mathrm{CH} \mathrm{HE}$ access via vocational baccalaureate

$13 \%$

$11 \%$

CA HE access via college or work preparatory courses

$14 \%$

$3 \%$

\begin{tabular}{llll}
\multicolumn{2}{l}{$\begin{array}{l}\text { Pathway 3: } \\
\text { Non-tertiary pathway with HE entry qualifications }\end{array}$} & $\begin{array}{l}\text { No immigrant } \\
\text { background }\end{array}$ & $\begin{array}{l}\text { Immigrant } \\
\text { background }\end{array}$ \\
\hline FR & All baccalaureate diplomas and no HE enrolment & $19 \%$ & $22 \%$ \\
CH & All baccalaureate diplomas and no HE enrolment & $19 \%$ & $19 \%$ \\
CA & All preparatory courses and no HE enrolment & $23 \%$ & $36 \%$
\end{tabular}

\section{Pathway 4:}

Non-tertiary pathway without HE entry qualifications

No immigrant Immigrant background background

FR Other (none baccalaureate) upper secondary diploma (VET)

$21 \%$

$27 \%$

$\mathrm{CH}$ Other (none baccalaureate) upper secondary diploma (VET)

$31 \%$

$43 \%$

CA No preparatory course

$2 \%$

$0 \%$ 


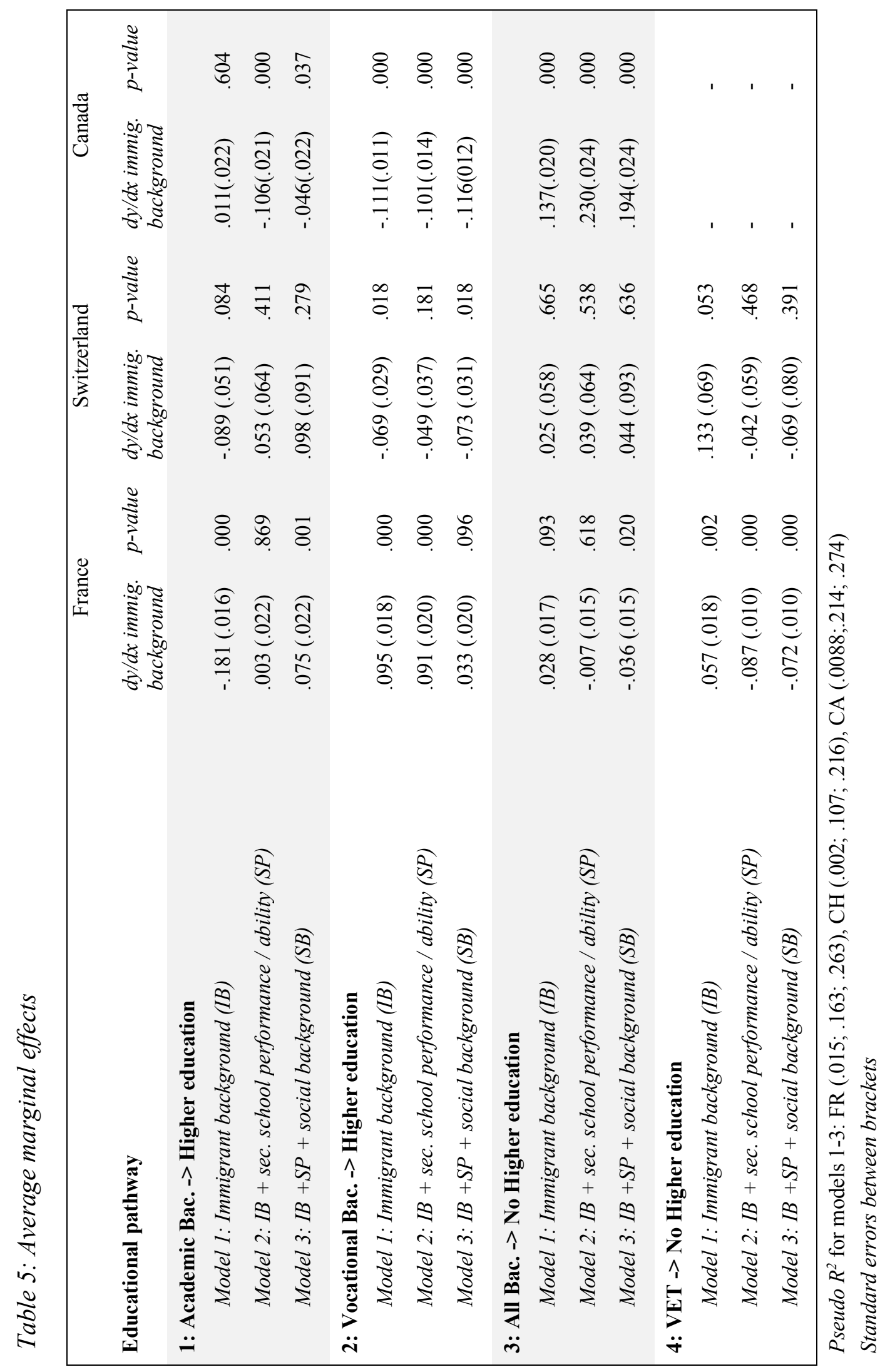

